\title{
Banks' Capital Structure Determinants: A Comparative Analysis Between Islamic and Conventional Banks based on Corporate and Regulatory Approaches
}

\author{
Kaouther Toumi, Associate professor \\ LGCO, University of Toulouse III - Paul Sabatier, France \\ kaouther.toumilajimi@univ-tlse3.fr
}

July 2021

\begin{abstract}
The research aims to empirically investigate the banks' capital structure determinants by considering 386 listed and unlisted banks categorized into 74 IBs, $256 \mathrm{CBs}$, and $56 \mathrm{HBs}$ from 20 countries for 2008-2016 based on corporate and regulatory approaches. The main findings are interesting. From a corporate approach, we find differences between IBs, CBs and HBs regarding the determinants of their capital structure which offer an empirical confirmation of the reduced information asymmetry in an Islamic finance context. From a regulatory approach, the findings show similarities regarding the negative impact of deposit insurance schemes on the regulatory capital for all types of banks. When focusing on IBs, we evidence that banks subject to Shari'ah-compliant deposit insurance schemes hold lower capital than those subject to conventional deposit insurance schemes.
\end{abstract}

\section{Keywords:}

Financial decision, Islamic ethics, Banks, Corporate finance theories, Regulation 


\section{Introduction}

Banks' corporate governance has become an important area attracting much international attention, especially after the 2008 financial crisis (De Haan and Vlahu 2016). Understanding capital structure is essential for banks as it affects their stability and ability to provide liquidity and credits effectively (Diamond and Rajan 2000). The past quarter-century of deregulation and the globalization of financial markets, combined with the rapid pace of financial innovation and the moral hazard caused by frequent government bailouts, caused a devastating financial crisis (Crotty 2009). Excessive leverage is one of the major causes of bank fragility during the financial crisis (Crotty 2009). This crisis also highlights the importance of considering banks' business models (Köhler 2014).

From a theoretical perspective, capital structure has always been a fundamental dimension of financial analysis, starting from the famous proposition of Modigliani and Miller (1958). When dealing with banks, the corporate approach of capital structure is observed to explain the capital structure of these financial institutions (Berger et al. 1995; Gropp and Heider 2010; Octavia and Brown 2010). Based on the regulatory approach, regulation and safety nets also significantly impact banks' capital structure (Diamond and Dybvig 1983; Berger et al. 1995; Gropp and Heider 2010; Octavia and Brown 2010; Allen et al. 2014). The existing empirical literature on banks are limited in scope concerning geography, for instance, the study of Gropp and Heider (2010) for listed US and UE banks and Berger et al. (1995) for listed US banks; or economic context (e.g., Octavia and Brown (2010) for banks in developing countries).

Islamic banks (Hereafter, IBs) capital structure is different in nature. IBs respect specific ethical principles (e.g., profit and loss sharing, ban on dealing with interest, tangibility and transparency requirement, ban on speculation and high risk-taking) making them distinctive. Such unique characteristics may influence IBs capital structure. Capital structure is a well-investigated area for conventional banks. For IBs, the capital structure is also important, and few researches have been conducted on the capital structure. To the best of our knowledge, no existing study compares IBs' capital structure with that of conventional banks (hereafter, CBs) and hybrid banks (hereafter, HBs). For IBs, empirical studies regarding financial decisions are emerging, and the existing literature considers mainly the corporate approach to explain IBs' capital structure (Bitar et al., 2018; Meslier et al., 2020; 
Guizani, 2021, Guizani and Ajmi, 2021). Hoque and Liu (2021) recently considered the regulatory approach but their study lacks considering the impact of safety nets and deposit insurance schemes on IBs capital structure. We complement the existing literature first by comparing three types of banks: IBs, conventional banks (Hereafter, CBs) and hybrid banks (Hereafter, HBs: conventional banks with Islamic windows) and second by considering the regulatory approach of capital structure with taking into consideration the impact of Shari'ahcompliant deposit insurance schemes on IBs regulatory capital.

The research aims to empirically investigate the banks' capital structure determinants by considering three types of banks. Our sample consists of 386 listed and unlisted banks categorized into 74 IBs, 256 CBs, and 56 HBs from 20 countries for 2008-2016. Depending on the considered approach, we integrate several measures of capital structure. Based on the corporate finance approach, we identify profitability, market to book ratio, dividend, collaterals, and size as bank-specific determinants of banks' leverage. When considering the regulatory approach, we add regulation and deposit insurance schemes, conventional and Shari'ah-compliant ones, as additional determinants of banks' regulatory capital.

The main findings are interesting. From a corporate approach, we find differences between IBs, CBs and HBs regarding the determinants of their capital structure which offer an empirical confirmation of the reduced information asymmetry in an Islamic finance context. From a regulatory approach, the findings show similarities regarding the negative impact of deposit insurance schemes on the regulatory capital for all types of banks. When focusing on IBs, we evidence that banks subject to Shari'ah-compliant deposit insurance schemes hold lower capital than those subject to conventional deposit insurance schemes.

Our results contribute to the literature on Islamic banking, developing markets, and the broader corporate finance capital structure literature in several important ways. Firstly, no other study addresses a world-level test of bank determinants of the capital structure under the three categorizations of IBs, CBs and HBs. Making several sup-samples to examine the determinants of bank capital structure contributes to a better understanding of whether Islamic ethical principles affect financial decisions. Secondly, the research considers separately listed and unlisted banks and contributes to the scarce literature dedicated to the capital structure of unlisted banks. The previous research focused mainly on listed banks (Caglayan and Sak 2010; Gropp and Heider 2010; Octavia and Brown 2010) or listed non-financial firms (Booth 
et al. 2001; Antoniou et al. 2008; Frank and Goyal 2009). Third, with using common banklevel measures, we empirically investigate the determinants of IBs financial decisions and find that standard and regulatory capital structure theories and empirical results can be applied to IBs.

The rest of this chapter is organized as follows. Section 2 gives the literature review. Section 3 specifies the research design. Section 4 describes the empirical results, and section 5 concludes.

\section{Islamic banks' capital structure and its determinants}

\subsection{Corporate approach}

The corporate finance theories on firm capital structure identified mainly taxation, bankruptcy costs, information asymmetries, and conflicts of interest as main drivers of firms' financial structure. These same theories are also considered to explain banks' capital structure (Berger et al. 1995; Gropp and Heider 2010; Octavia and Brown 2010). Considering the Islamic finance ethics in the classical theories of capital structure could lead to different conclusions for IBs. Toumi et al. (2012) conduct a first theoretical explanation of IBs' capital structure from a corporate approach and suggest that the trade-off arguments are similar, but the pecking order arguments are weaker compared to CBs.

The trade-off theory suggests that the optimal capital structure results from a trade-off between tax benefits and expected bankruptcy costs (Modigliani and Miller 1958; Myers 1984). Considering the Islamic finance context, the level of bankruptcy costs could be theoretically lower compared with CBs. On one side, the religious beliefs of IBs customers may induce loyalty and decrease default and bankruptcy costs (Abedifar et al., 2013). On the other side, several features related to Islamic finance make IBs conceptually less vulnerable to risk and thus reduce default costs (e.g., the traceability requirement in Islamic financial transactions, the profit and loss sharing scheme, limited access to speculative and risky asset classes). Based on the trade-off theory contributions, Toumi et al. (2012) suggest that the capital ratio is lower theoretically due to decreased bankruptcy costs in IBs and that the tax burden related to liabilities is calculated similarly for both IBs and CBs. 
The pecking order theory suggests that firms prefer internal to external financing and debt to equity due to information asymmetry between firm insiders and outside investors (Myers 1984; Myers and Majluf 1984). From this perspective, banks are highly leveraged as these institutions are known to be opaque institutions, especially with respect to asset and loan portfolio risk characteristics and quality (Mülbert 2009). However, information asymmetries are addressed differently when considering Islamic finance ethics (Toumi et al. 2012). Transparency in financial contracts and agreements is mandatory, and all stakeholders need to be morally responsible with respect to each other to avoid a situation of incomplete information (Toumi et al. 2012; Abdelsalam et al. 2016). All players are required to fulfill the religious obligation of Amana (trust), forcing them to behave with respect to justice (Adl), balance (Qist), and perfection (Ihsaan) principles. This feature permits each stakeholder to benefit from equal, adequate, and accurate information, thus reducing information asymmetries. Furthermore, the traceability requirement in Islamic arrangements, the strong link with the real economy, and the restricted set of investment opportunities allow outside investors to have a clearer view of IB assets quality (Toumi et al. 2012). The Shariah governance ensured by SSB also plays a central role in reducing information asymmetries in IBs since it ensures that the financial interests of all stakeholders are protected, that IB behavior complies with Islamic finance ethics, and that the transparency principle is respected (Toumi et al. 2012; Abdelsalam et al. 2016; Farag et al. 2017). Based on the contributions of pecking order theory, Toumi et al. (2012) suggest that pecking order arguments are weaker in IBs as lower information asymmetries is expected in this context, and thus IBs should have a higher capital ratio compared to CBs.

Third, the agency theory states that firms face a trade-off between equity and non-equity financing due to agency costs. The optimal capital structure is obtained by arbitration between debt benefits that reduce agency conflicts between shareholders and managers, and agency costs of debt resulting from asset substitution effect and conflict of interest between shareholders and debt holders (Jensen and Meckling 1976; Myers 1977; Jensen 1986; Williamson 1986; Harris and Raviv 1990). For IBs, the agency structure is more complex since the corporate structure deviates from the conventional forms and managers act in a Shariah-compliant manner besides maximizing their shareholders' wealth (Archer et al. 1998), as revealed in Table 1. Based on the agency theory, Toumi et al. (2012) suggest that the optimal capital structure in IBs will be obtained by trading off between benefits and costs related to different agency relationships. They conclude that IBs should have a different 
capital ratio compared with $\mathrm{CBs}$ when considering the new and the classical agency relationships.

Table 1: Agency relationships in IBs

\begin{tabular}{|c|c|c|c|}
\hline $\begin{array}{c}\text { Nature } \\
(1)\end{array}$ & Agency relationship ident & $\begin{array}{l}\text { ied in the literature for IBs and comparison with } \\
\text { CBs } \\
\text { (2) }\end{array}$ & $\begin{array}{l}\text { Potential impact on } \\
\text { IB capital structure } \\
\text { (3) }\end{array}$ \\
\hline \multirow[t]{2}{*}{ Traditional } & $\begin{array}{c}\text { Shareholders-Liability } \\
\text { claim holders } \\
\text { (Archer et al. 1998; } \\
\text { Safieddine 2009; Toumi et } \\
\text { al. 2012; Abdelsalam et al. } \\
\text { 2016; Farag et al. 2017) }\end{array}$ & $\begin{array}{l}\text { Lower agency costs in IBs because of the limited } \\
\text { possibilities of wealth transfers from shareholders } \\
\text { to claim holders due to the impossibility for } \\
\text { shareholders to engage in speculative and highly } \\
\text { risky projects (Toumi et al. 2012). }\end{array}$ & $\begin{array}{l}\text { Favoring liabilities } \\
\text { claim holders }\end{array}$ \\
\hline & $\begin{array}{l}\text { Shareholders-managers } \\
\quad \text { (Archer et al. 1998; } \\
\text { Safieddine 2009; Toumi et } \\
\text { al. 2012; Beck et al. 2013; } \\
\text { Abdelsalam et al. 2016; } \\
\text { Farag et al. 2017) }\end{array}$ & $\begin{array}{l}\text { Lower agency costs in IBs result from higher moral } \\
\text { accountability and required transparency that } \\
\text { encourages managers to be morally responsible } \\
\text { with respect to shareholders (Toumi et al. 2012; } \\
\text { Abdelsalam et al. 2016). }\end{array}$ & Favoring equity \\
\hline \multirow[t]{2}{*}{$\begin{array}{c}\text { New } \\
\text { (with PSIA } \\
\text { depositors) }\end{array}$} & $\begin{array}{l}\text { PSIA depositors-managers } \\
\text { (Archer et al. 1998; } \\
\text { Safieddine 2009; Toumi et } \\
\text { al. 2012; Abdelsalam et al. } \\
\text { 2016; Farag et al. 2017) }\end{array}$ & $\begin{array}{l}\text { Additional agency costs in IBs since managers act } \\
\text { as agents of PSIA depositors (Toumi et al. 2012). } \\
\text { Managers are free to decide how PSIA funds are } \\
\text { invested and do not empower PSIA depositors to } \\
\text { monitor their investment through representation in } \\
\text { the board of directors (Abdelsalam et al. 2016). } \\
\text { Even if the depositors' means of pressure to control } \\
\text { managers appear to be more limited than those of } \\
\text { shareholders, they nevertheless have others mean } \\
\text { through the threat of withdrawing funds; PSIA } \\
\text { holders also exert disciplinary control on managers } \\
\text { via shareholders (Toumi et al. 2012). }\end{array}$ & Favoring equity \\
\hline & $\begin{array}{l}\text { PSIA depositors- } \\
\text { shareholders } \\
\text { (Toumi et al. 2012) }\end{array}$ & $\begin{array}{l}\text { Additional agency costs in IBs. Agency conflicts } \\
\text { regarding the bank risk level exist between PSIA } \\
\text { depositors and shareholders, but they are far less } \\
\text { important than those between shareholders and debt } \\
\text { holders (because of the similarities of their } \\
\text { incentives). An increase in risk could generate a } \\
\text { wealth transfer from debt holders to shareholders, } \\
\text { but for PSIA holders, the problem is only of non- } \\
\text { optimal risk level (Toumi et al. 2012). }\end{array}$ & $\begin{array}{c}\text { Favoring PSIA } \\
\text { deposits }\end{array}$ \\
\hline $\begin{array}{l}\text { New } \\
\text { (with the } \\
\text { Shariah } \\
\text { Supervisory } \\
\text { Board) }\end{array}$ & $\begin{array}{l}\text { Managers- Shariah } \\
\text { Supervisory Board } \\
\text { (Toumi et al. 2012; } \\
\text { Abdelsalam et al. 2016) }\end{array}$ & $\begin{array}{l}\text { Additional agency costs in IBs result from } \\
\text { difficulties for the SSB to exert control on } \\
\text { managers to ensure that they operate in accordance } \\
\text { with Islamic finance ethics. These difficulties } \\
\text { should be of the same type and magnitude as those } \\
\text { extensively studied in the literature on the board of } \\
\text { directors (Toumi et al. 2012). The existence of this } \\
\text { second layer of governance is expected to limit } \\
\text { opportunities for financial misstatements and } \\
\text { consequently moderate the higher agency costs in } \\
\text { IBs (Abdelsalam et al. 2016). The committee is } \\
\text { expected to act in the best interests of all } \\
\text { stakeholders (shareholders, PSIA depositors, } \\
\text { claimholders) (Toumi et al. 2012). }\end{array}$ & $\begin{array}{l}\text { Favoring non-equity } \\
\text { or equity financing }\end{array}$ \\
\hline
\end{tabular}


Based on the corporate approach, the empirical literature identified mainly market to book ratio, profitability, collaterals, size, and dividend payout as standard determinants that are reliably related to firm leverage ( Titman and Wessels, 1988; Harris and Raviv, 1991; Rajan and Zingales, 1995; Frank and Goyal, 2009). Similar recent studies using the same variables have emerged for banks (Gropp and Heider 2010; Octavia and Brown 2010).

Regarding profitability, more profitable firms will have more internal funding, decreasing the need for external financing. Following pecking order, a negative relationship between leverage and profitability is expected. Trade-off theory suggests the opposite result. Trade-off theory suggests that profitable firms increase debts because firstly, they find interesting tax shields, and secondly, they face lower expected bankruptcy costs. The most profitable firms have more facilities to take on more debt, since the probability of repayment is higher. As for IBs the pecking order arguments are weaker, we expect a higher impact of profitability on the leverage ratio for IBs than for CBs.

For collaterals, a high proportion helps firms raise more debts secured by these assets based on trade-off theory. Based on agency theory, using assets as collaterals limits the ability of shareholders to engage in risk-taking behavior that significantly reduces debtholders' exposure to asset substitution effect and increases leverage (Jensen and Meckling 1976). Pecking order theory suggests that firms with a high proportion of collaterals are less sensitive to information asymmetries, thus favoring equity. As for IBs the pecking order arguments are weaker, for IBs we expect a lower impact of tangibility on the equity ratio than for CBs.

With regards to size, large banks would be exposed to a low risk of bankruptcy that favors leverage following trade-off theory. Large firms have easier access to bank credit market. Gropp and Heider (2010) and Octavia and Brown (2008) confirm this result for the banking sector. Following pecking order theory, information asymmetries is lower in large firms which should encourage equity financing. As for IBs the trade-off arguments are similar and asymmetry is lower, we expect that size will have a greater positive impact on the leverage ratio.

Finally, with regards to dividend, the pecking order theory suggests that paying dividends helps to reduce information asymmetries since it allows information to be conveyed, thus increasing equity. Dividend-paying firms transmit a good signal regarding future prospects and could easily attract investors (Lintner 1965). Following agency theory, 
shareholders may use dividends as a strategic weapon to discipline managers and align with their interests. As asymmetry of information and agency conflict should be less important in IBs, we expect that the impact of dividends should be lower on the equity ratio than the one expected for CBs.

Regarding market to book ratio, a high value reflects greater investment opportunities that give shareholders greater choices for future investments. According to the trade-off theory, firms with high growth investment opportunities have higher bankruptcy costs that limit leverage. Regarding agency theory, growth options promote the alignment of interests, and equity financing is thus a choice (Jung et al. 1996). However, if growth opportunities are low, debt is the appropriate vehicle to discipline managers (Jensen 1986; Stulz 1990). From a pecking order perspective theory, firms with high growth opportunities and significant funding requirements will primarily use external financing, which is less subject to asymmetric information (Myers 1984; Myers and Majluf 1984). We expect that the impact of market to book ratio on equity ratio will be higher for IBs than for CBs.

From a corporate approach, as the trade-off arguments are similar and the pecking order arguments is weaker for IBs, we expect thus a different impact of standard corporate determinants (Size, Market to book, Profitability, Collaterals, Dividend payout) on IBs' capital structure, compared to conventional banks (Hypothesis 1).

\subsection{Regulatory approach}

Banks differ substantially from non-financial firms by the nature of debts and the special treatment in the form of government safety net and prudential regulation (Merton 1977; Diamond and Dybvig 1983; Berger et al. 1995; Miller 1995; Macey and O'Hara 2003; Gropp and Heider 2010; Octavia and Brown 2010; Allen et al. 2014). Such protection from bankruptcy and the costs of financial distress affects capital requirements for banks (Berger et al. 1995). From a regulatory point of view, regulators could force riskier banks to hold more regulatory capital to protect themselves against costs of financial distress (Berger et al. 1995; Gropp and Heider 2010; Octavia and Brown 2010).

In the Islamic banking context, the ability to engage in reckless economic behavior, as well as the incentives shareholders to increase risks, are limited firstly by the requirement to conform to Islamic finance morals and secondly, by the availability of SSB in the governance 
structure that guarantees to all stakeholders' compliance with Islamic finance rules. The business model of IBs should conceptually allow IBs to pass through adverse shocks more easily, thereby decreasing the costs of financial distress. We expect a lower impact of risk on $I B s^{\prime}$ regulatory capital than CBs (Hypothesis 2).

The government safety net includes deposit insurance, unconditional payment guarantees, and the entire panoply of regulation and supervision that is not directly related to capital (Berger et al. 1995; Calomiris 1999). Banks resort to safety nets as a means of extreme liquidity risk management that stabilizes the financial system and protects small and uninformed depositors from adverse shocks and associated costs (Diamond and Dybvig 1983). Safety net policies limit depositors' tendency to overreact by changing the incentives of depositors (Calomiris 1999). Safety nets tend to reduce the bank level of capital requirement since their introduction reduces the likelihood of bank failure and isolates banks from the potential market discipline (Berger et al. 1995). Higher deposit insurance coverage is thus associated with higher leverage and lower capital requirement in banks than others with similar portfolios not subject to deposit insurance. IBs hold safer portfolios and, consequently, less regulatory capital is theoretically required than CBs. IBs do not have to provide liquidity insurance to Mudarabah-based profit-sharing investment account holders. However, several studies highlight the divergence between the treatment of investment accounts in practice and the theoretical conception (Archer and Karim 2006, 2009; El-Hawary et al. 2007; Farook et al. 2012; Toumi and Viviani 2013). When IBs' returns on investment accounts are weak, their depositors could exercise power over the IB managers due to their ability to withdraw their deposits (Toumi et al. 2012; Aysan et al. 2016). To avoid massive withdrawal of funds and market discipline that IBs' depositors could exercise upon negative information indicating poor investment returns, IBs may be constructively obliged to manage the payout of profits to investment account holders, mainly with the absence of adequate tools for that purpose compared with CBs (Farook et al. 2012; Toumi et al. 2018).

Most IBs do not benefit from Islamic protection schemes in several jurisdictions, and their deposits are mostly protected under conventional schemes ${ }^{\mathrm{a}}$. Aysan et al. (2016) observe that deposit insurance affects the incentives of IBs' depositors to exert market discipline as in

\footnotetext{
a Main differences exist with conventional schemes (IFSB, 2011). First, products covered under deposit insurance are Islamic deposits and may be extended to PSIAs. Second, members are IBs. Third, premiums are paid from IBs' funds. In the case of PSIAs, premiums may be paid from PSIAs funds. Finally, expenses incurred and any investment of premiums should comply with ethical principles of Islamic finance.
} 
a conventional context. More interestingly, their study reveals that the nature of deposit insurance, being Islamic or conventional, impacts the intensity of the market discipline of IBs' depositors. Conventional deposit insurance schemes appear to increase the market discipline of IBs' depositors, compared with a situation where IBs are protected by Shari'ah-compliant deposit insurance schemes (Aysan et al. 2015, 2016). IBs' depositors show a greater tendency to discipline their banks if the deposit insurance lacks religious quality and is not compliant with Islamic finance rules.

We expect, thus, a different impact of the Shariah-compliant deposit insurance schemes on the regulatory capital of IBs, compared to conventional deposit insurance schemes (Hypothesis 3).

\section{Research design}

\subsection{Sample}

We consider three categories of banks: Islamic banks (IBs), conventional banks (CBs) and hybrid banks (HBs: CBs with Islamic windows). We consider both listed and non-listed banks. In contrast to the literature, which usually examines listed banks (Berger et al. 1995; Gropp and Heider 2010; Octavia and Brown 2010), we include unlisted banks to give a more representative picture of the banking sector ${ }^{\mathrm{b}}$.

We collect Data from the Bankscope database. We considered banks with codes C1, C2, and $\mathrm{C}^{*}$ as they publish consolidated financial statements (Mollah et al., 2016). Then, we checked for the categories of banks. We note that first, some IBs are missingly classified as CBs. Second, Bankscope does not classify HBs as a third category. To solve such a problem, we manually scanned the financial services provided by banks through consulting their websites. We then filtered the remaining banks by considering only countries having both Islamic and conventional banks.

\footnotetext{
b Listed banks are typically larger, have significantly higher non-deposit funding, and are usually more closely monitored by the market than banks that could force managers to expand into more risky non-interest income activities (Köhler 2014). Listed banks are also controlled by institutional investors with greater expertise in processing information and monitoring managers and can exert greater control than atomistic shareholders (Köhler 2014). Furthermore, listed banks usually have a more dispersed ownership structure giving their managers greater scope to generate private benefits of control than unlisted banks (Barry et al. 2011).
} 
Our final sample covers 386 banks implemented in 20 countries over the period 2008-2016.

Banks are categorized into $74 \mathrm{IBs}, 256 \mathrm{CBs}$, and $56 \mathrm{HBs}$.

\begin{tabular}{|c|c|c|c|c|c|c|c|c|c|c|}
\hline & \multicolumn{3}{|c|}{$\begin{array}{l}\text { Panel A: Islamic banks } \\
\text { (IBs) }\end{array}$} & \multicolumn{3}{|c|}{$\begin{array}{c}\text { Panel B: Conventional } \\
\text { banks (CBs) }\end{array}$} & \multicolumn{3}{|c|}{$\begin{array}{c}\text { Panel C: Hybrid banks } \\
\text { (HBs) }\end{array}$} & \multirow{2}{*}{$\begin{array}{c}\text { Panel D: All } \\
\text { banks } \\
\text { Total }\end{array}$} \\
\hline & Listed & Unlisted & Total & Listed & Unlisted & Total & Listed & Unlisted & Total & \\
\hline Bahrain & 4 & 3 & 7 & 4 & 4 & 8 & 1 & 1 & 2 & 17 \\
\hline $\begin{array}{c}\text { Brunei } \\
\text { Darussalam }\end{array}$ & 0 & 1 & 1 & 0 & 1 & 1 & 0 & 0 & 0 & 2 \\
\hline Egypt & 3 & 0 & 3 & 8 & 10 & 18 & 1 & 3 & 4 & 25 \\
\hline Indonesia & 1 & 5 & 6 & 23 & 21 & 44 & 12 & 5 & 17 & 67 \\
\hline Iraq & 1 & 2 & 3 & 5 & 0 & 5 & 0 & 0 & 0 & 8 \\
\hline Jordan & 2 & 1 & 3 & 9 & 0 & 9 & 0 & 0 & 0 & 12 \\
\hline Kuwait & 3 & 0 & 3 & 4 & 1 & 5 & 0 & 0 & 0 & 8 \\
\hline Lebanon & 0 & 1 & 1 & 4 & 29 & 33 & 1 & 1 & 2 & 36 \\
\hline Malaysia & 1 & 16 & 17 & 3 & 18 & 21 & 0 & 5 & 5 & 43 \\
\hline Oman & 0 & 0 & 0 & 1 & 0 & 1 & 4 & 1 & 5 & 6 \\
\hline Qatar & 3 & 1 & 4 & 3 & 1 & 4 & 2 & 0 & 2 & 10 \\
\hline Saudi Arabia & 4 & 0 & 4 & 3 & 0 & 3 & 4 & 0 & 4 & 11 \\
\hline Singapore & 0 & 1 & 1 & 4 & 9 & 13 & 0 & 0 & 0 & 14 \\
\hline Syria & 2 & 0 & 2 & 7 & 1 & 8 & 0 & 0 & 0 & 10 \\
\hline Thailand & 0 & 1 & 1 & 9 & 8 & 17 & 0 & 1 & 1 & 19 \\
\hline Tunisia & 0 & 1 & 1 & 10 & 4 & 14 & 0 & 0 & 0 & 15 \\
\hline Turkey & 3 & 1 & 4 & 12 & 14 & 26 & 0 & 0 & 0 & 30 \\
\hline UAE & 6 & 2 & 8 & 5 & 1 & 6 & 7 & 1 & 8 & 22 \\
\hline UK & 2 & 0 & 2 & 7 & 11 & 18 & 1 & 5 & 6 & 28 \\
\hline Yemen & 0 & 4 & 4 & 0 & 2 & 2 & 0 & 0 & 0 & 6 \\
\hline Total & 35 & 39 & 74 & 121 & 135 & 256 & 33 & 23 & 56 & 386 \\
\hline
\end{tabular}

\subsection{Variables specification}

From a corporate finance approach, the empirical literature identified mainly market to book ratio (MTB), profitability (Prof), collaterals (Coll), size, and dividend payout (Div) that are reliably related to firm leverage (Frank and Goyal, 2009; Harris and Raviv, 1991; Rajan and Zingales, 1995; Titman and Wessels, 1988). Similar recent studies have emerged for conventional banks (Gropp and Heider 2010; Octavia and Brown 2010).

From a regulatory approach, we also consider the bank risk (Risk) and the availability of an explicit conventional deposit insurance scheme (DepIns) and an Islamic deposit insurance scheme (ShDepIns). We also consider the following control variables, the gross domestic product per capita (GDP) and Inflation (Inf), as in Gropp and Heider (2010) and Bitar et al (2018). As for the macroeconomic factors, they reflect the environment in which 
banks operate. In order to avoid effect of outliers, all variables are winzorized at $0.5 \%$ and 99.5\% (See Table 2).

Table 2: Variables definitions

\begin{tabular}{|c|c|c|}
\hline Variables & Definitions & Sources \\
\hline Leverage & 1- Equity to total assets & Bankscope \\
\hline RegCapital & Tier 1 capital divided by risk-weighted assets & Bankscope \\
\hline Deposits & $\begin{array}{l}\text { Total customer deposits (current, saving, and term) to total } \\
\text { assets. For IBs, deposits correspond to Mudharaba and non- } \\
\text { Mudharaba based deposits: unrestricted PSIAs + Murabaha } \\
\text { deposits, medium-term Wakala financing + saving accounts } \\
\text { + current accounts }\end{array}$ & Bankscope \\
\hline NDeposits & Leverage ratio minus deposits ratio & $\begin{array}{l}\text { Author's Calculation } \\
\text { from Bankscope }\end{array}$ \\
\hline MTB & Market value of assets to book value of assets & Bankscope \\
\hline Prof & Return on average assets. & Bankscope \\
\hline Coll & $\begin{array}{l}\text { Total securities }+ \text { Cash and due from banks }+ \text { derivatives }+ \\
\text { Land and buildings }+ \text { other tangible assets. } \\
\text { For IBs, there are no conventional derivatives }\end{array}$ & $\begin{array}{l}\text { Author's Calculation } \\
\text { from Bankscope }\end{array}$ \\
\hline Size & Ln (total assets) & Bankscope \\
\hline Div & $\begin{array}{l}\text { Dummy variable that takes the value of } 1 \text { if the bank pays a } \\
\text { dividend in a given year, zero otherwise }\end{array}$ & Bankscope \\
\hline DepIns & $\begin{array}{l}\text { Dummy variable that takes the value of } 1 \text { if explicit deposit } \\
\text { insurance is available and zero otherwise }\end{array}$ & $\begin{array}{l}\text { International } \\
\text { Association of Deposit } \\
\text { Insurers www.iadi.org }\end{array}$ \\
\hline ShDepIns & $\begin{array}{l}\text { Dummy variable that takes the value of } 1 \text { if there is separate } \\
\text { deposit protection for IBs and } \mathrm{CBs} \text { in a given jurisdiction } \\
\text { and the value of } 0 \text { if there is a single conventional deposit } \\
\text { protection scheme for all banks }\end{array}$ & $\begin{array}{l}\text { International } \\
\text { Association of Deposit } \\
\text { Insurers www.iadi.org } \\
\text { and IFSB website } \\
\text { www.ifsb.org }\end{array}$ \\
\hline Risk & $\begin{array}{l}\ln (\mathrm{z} \text {-score }) \text {. The value is equal to } \ln \text { [(return on average } \\
\text { assets + capital to assets ratio)/Standard deviation of return } \\
\text { on average assets over three years] }\end{array}$ & $\begin{array}{l}\text { Author's calculation } \\
\text { from Bankscope }\end{array}$ \\
\hline GDP & The annualized growth rate of GDP per capita & World Bank database \\
\hline Inflation & Inflation rate. & World Bank database \\
\hline
\end{tabular}

\subsection{Econometric modeling}

We run first the corporate standard regression on Leverage of IBs, CBs and HBs as in Gropp and Heider (2010). The corporate literature consider Market to book, profitability, collaterals, size and dividend payout as the main variables explaining firm's capital structure ( Gropp and Heider 2010; Octavia and Brown 2010; Frank and Goyal, 2009; Harris and Raviv, 1991; Rajan and Zingales, 1995; Titman and Wessels, 1988) (See Eq.1).

$$
\begin{aligned}
& \text { Leverage }_{i, t}=\beta_{0}+\beta_{1} \text { MTB }_{i, t-1}+\beta_{2} \text { Prof }_{i, t-1}+\beta_{3} \text { Coll }_{i, t-1}+\beta_{4} \text { Size }_{i, t-1}+\beta_{5} \text { Div }_{i, t}+ \\
& \text { GDP }_{t}+\text { Inflation }_{t}+\varepsilon_{i, t}
\end{aligned}
$$


We then break it down into Deposits and NDeposits to test the standard regression on leverage components of banks. The corporate finance literature does not explicitly distinguish between debt and non-debt liabilities. However, the financial structure of banks differs from non-financial firms by including deposits, a source of financing generally not available to firms (Miller, 1995). We also consider listed and unlisted banks separately.

In equation 2, we investigate the regulatory approach of bank capital structure, and we test the potential effect of Risk and the availability of an explicit deposit insurance scheme (DepIns) on the regulatory capital (RegCapital) and leverage. For IBs, we test the impact of introducing the Islamic explicit deposit insurance scheme (ShDepIns) to capture the impact of IB depositors' market discipline. We also regress the same variables of equation 2 on leverage and the component of leverage.

$$
\begin{aligned}
& \text { RegCapital }_{i, t}=\beta_{0}+\beta_{1} \text { MTB }_{i, t-1}+\beta_{2} \text { Prof }_{i, t-1}+\beta_{3} \text { Coll }_{i, t-1}+\beta_{4} \text { Size }_{i, t-1}+ \\
& \beta_{5} \text { Div }_{i, t}+\beta_{6} \text { Risk }_{i, t}+\beta_{7} \text { DepIns }_{i, t}+G D P_{t}+\text { Inflation }_{t}+\varepsilon_{i, t}
\end{aligned}
$$

\section{Regression results}

\subsection{Descriptive statistics}

Table 4 provides descriptive statistics. Descriptive analysis reveals that, although IBs hold on average a lower proportion of deposits $(65.52 \%$ vs. $66.88 \%$ for CBs and $70.53 \%$ for HBs), they are observed to have the highest capital ratio (15.8\% for IBs vs. $13 \%$ for CBs and $12.23 \%$ for HBs). Similarly, the regulatory capital ratio for IBs is $17.53 \%$ compared with $16.37 \%$ for CBs and $14.17 \%$ for HBs. Results also show that IBs record on average lower return on assets ( $1.10 \%$ vs. $1.26 \%$ for $\mathrm{CBs}$ and $1.77 \%$ for $\mathrm{HBs})$. Regarding the market to book ratio, IBs are observed to have a higher value compared with CBs (1.73\% vs. $1.49 \%$ ) and a lower value than that of HBs $(1.93 \%)$. Furthermore, the value of collaterals is lower in IBs $(47.89 \%)$ compared with CBs (51.08\%). HBs are observed to have, on average, a lower proportion of Collaterals (41.11\%). Regarding bank size, IBs are relatively smaller (14.57) compared with CBs (14.98). Results regarding risk indicate that IBs have the lowest value on average (3.31 for IBs vs. 3.73 for CBs and 3.79 for HBs). 
Table 4: Descriptive statistics

\begin{tabular}{|c|c|c|c|c|c|c|c|c|c|c|}
\hline \multirow{2}{*}{ Variables } & \multicolumn{2}{c|}{$\begin{array}{c}\text { Panel A: } \\
\text { Islamic banks } \\
\text { (IBs) }\end{array}$} & $\begin{array}{c}\text { Panel B: } \\
\text { Conventional } \\
\text { banks (IBs) }\end{array}$ & $\begin{array}{c}\text { Panel C: } \\
\text { Hybrid banks } \\
\text { (HBs) }\end{array}$ & \multicolumn{3}{|c|}{ Panel D: All banks } \\
\hline & Mean & SD & Mean & SD & Mean & SD & Mean & SD & Max & Min \\
RegCapital & 17.53 & 8.42 & 16.37 & 7.42 & 14.17 & 4.31 & 16.18 & 7.23 & 51.04 & 4.67 \\
leverage & 84.19 & 10.70 & 87 & 8.24 & 87.76 & 6.41 & 86.61 & 8.57 & 96.96 & 40.09 \\
NDeposits & 20.93 & 20.57 & 20.84 & 17.37 & 17.22 & 13.79 & 20.30 & 17.55 & 94.18 & 0.24 \\
Deposits & 65.52 & 21.18 & 66.88 & 18.42 & 70.53 & 15.04 & 67.21 & 18.52 & 95.46 & 2.25 \\
MTB & 1.73 & 1.24 & 1.49 & 0.88 & 1.93 & 1.02 & 1.62 & 1.001 & 7.96 & 0.02 \\
Prof & 1.10 & 2.47 & 1.26 & 1.64 & 1.77 & 1.28 & 1.31 & 1.78 & 11.17 & -10.3 \\
Coll & 47.33 & 21.40 & 51.08 & 21.64 & 41.11 & 13.48 & 48.93 & 20.88 & 99.48 & 8.48 \\
Div & 0.48 & 0.46 & 0.47 & 0.34 & 0.56 & 0.29 & 0.48 & 0.37 & 1 & 0 \\
Size & 14.57 & 1.50 & 14.98 & 2.06 & 15.68 & 1.6 & 15.01 & 1.94 & 21.55 & 7.81 \\
Risk & 3.31 & 1.11 & 3.73 & 1.11 & 3.79 & 1.02 & 3.67 & 1.11 & 6.91 & 0.14 \\
Inflation & 4.78 & 4.34 & 4.44 & 3.57 & 4.83 & 3.44 & 4.56 & 3.71 & 26.17 & -15.1 \\
GDP & 5.04 & 5.39 & 5.4 & 4.32 & 5.28 & 3.58 & 5.32 & 4.46 & 53.23 & -10.1 \\
\hline
\end{tabular}

Table 5 provides the matrix of Pearson correlation coefficients and indicates a relatively weak association between the variables on average. $M T B$ appears to be positively correlated to Prof implying that banks with high market-to-book ratio tend have high profitability. Besides, a positive relationship is observed between Prof and Div suggesting that banks with high profitability tend to pay high dividend. A similar relationship is detected between Prof and Risk showing that high profitable banks tend to be riskier. Furthermore, greater banks (Size) tend to pay more dividends (Div) and record higher levels of Risk. Finally, the negative correlation between DepIns and Risk highlights that riskier banks tend to benefit more from deposit insurance schemes. Finally, we note that no problem of multicollinearity is detected based on VIF tests.

Table 5: Correlation matrix

\begin{tabular}{|c|c|c|c|c|c|c|c|c|c|}
\hline & MTB & Prof & Coll & Size & Div & DepIns & Risk & Inflation & GDP \\
\hline MTB & 1 & & & & & & & & \\
Prof & $0.12^{* *}$ & 1 & & & & & & & \\
Coll & $-0.11^{* *}$ & $-0.05^{* *}$ & 1 & & & & & & \\
Size & 0.02 & -0.001 & $-0.22^{* *}$ & 1 & & & & \\
Div & -0.01 & $0.18^{* *}$ & 0.009 & $0.17^{* *}$ & 1 & & & \\
DepIns & $-0.12^{* *}$ & $-0.12^{* *}$ & $0.09^{* *}$ & -0.02 & $-0.10^{* *}$ & 1 & & & \\
Risk & $-0.09^{* *}$ & $0.18^{* *}$ & $-0.04^{*}$ & $0.11^{* *}$ & $0.23^{* *}$ & $0.07^{* *}$ & 1 & & \\
Inflation & $0.16^{* *}$ & $0.18^{* *}$ & 0.022 & $-0.14^{* *}$ & -0.01 & $-0.034^{*}$ & $0.05^{* *}$ & 1 & \\
GDP & -0.05 & $0.09^{* *}$ & 0.037 & $-0.19^{* *}$ & 0.001 & $-0.28^{* *}$ & $-0.08^{* *}$ & $0.15^{* *}$ & 1 \\
\hline
\end{tabular}




\subsection{Regression results: the standard corporate approach}

Table 6 presents the results related to capital structure determinants based on the corporate approach. Models 1 and 2 give results related to the determinants of banks' leverage, whereas Models 3-6 present results related to leverage components.

Models 1 and 2 give results on the determinants of leverage for listed and unlisted banks, respectively. When considering listed banks, the findings show the significance of all variables at $1 \%$ and $5 \%$ levels and suggest that the standard determinants of capital structure apply to listed banks. These findings align with those of Gropp and Heider (2010) for listed US and EU large banks and those of Octavia and Brown (2010) for banks in developing countries. A pure regulatory view is thus observed to be not the only explanation for the capital structure of listed banks; the standard corporate approach also contributes to it.

Globally, we find that larger listed banks with the greater market to book ratio, greater dividend payout, lower profitability, and lower collaterals tend to be more leveraged. Our results align with those of Octavia and Brown (2010) for listed banks in developing countries but are slightly different from those of Gropp and Heider (2010) for listed banks from developed countries. For instance, one possible explanation for the positive relation between market to book ratio and bank book leverage is that a high value reflects overpricing in the capital market. As suggested by the pecking order theory, the high degree of information asymmetry between the bank insiders and the market therefore results in banks issuing more debt (Octavia and Brown, 2010). In addition, the positive relation between dividends and bank book leverage indicates the relatively higher cost of having equity. Banks that commit to paying out dividends to their shareholders prefer to finance their operations with debt. Furthermore, the negative association of profitability with leverage could be explained under the pecking order theory that argues that firms prefer internal financing over external funds, allowing more profitable firms to be less levered over time. Finally, the negative impact of collaterals could also be explained under the pecking order theory that suggests that banks with a high proportion of collaterals are less sensitive to information asymmetries, thus favoring equity and lowering leverage. 
Regarding unlisted banks, the standard corporate regression explains less bank leverage ratio with only profitability and size having a negative and positive impact respectively at the 5\% and $1 \%$ significance levels. Larger unlisted banks with lower profitability tend to be more leveraged than listed banks. Our results are in line with Bitar et al. (2018) suggesting that the effect of classical determinants on the capital ratios of banks is also driven by the disciplinary role that the financial markets play in the capital structure decisions of publicly listed banks, compared to unlisted banks.

Table 6: Capital structure determinants. All banks. Period 2008-2016

\begin{tabular}{|c|c|c|c|c|c|c|}
\hline & \multicolumn{2}{|c|}{ Leverage } & \multicolumn{2}{|c|}{ Deposits Ratio (Deposits) } & \multicolumn{2}{|c|}{$\begin{array}{l}\text { Non-Deposits Ratio } \\
\text { (Ndeposits) }\end{array}$} \\
\hline & Listed & Unlisted & Listed & Unlisted & Listed & Unlisted \\
\hline $\begin{array}{l}\text { MTB t-1 } \\
\text { (Std Err) }\end{array}$ & $\begin{array}{c}(1) \\
1,02 * * * \\
(0.2)\end{array}$ & (2) & $\begin{array}{c}(3) \\
-0,12 \\
(0.3)\end{array}$ & (4) & $\begin{array}{c}(5) \\
0,75^{* * *} \\
(0.2)\end{array}$ & (6) \\
\hline $\operatorname{Prof}_{t-1}$ & $\begin{array}{c}-0,86^{* * *} \\
(0.1)\end{array}$ & $\begin{array}{c}-0,08^{*} \\
(0.1)\end{array}$ & $\begin{array}{c}-0,4^{* * *} \\
(0.3)\end{array}$ & $\begin{array}{l}0,45 \\
(0.5)\end{array}$ & $\begin{array}{l}-0,31 \\
(0.3)\end{array}$ & $\begin{array}{l}-0,49 \\
(0.55)\end{array}$ \\
\hline Coll $_{\mathrm{t}-1}$ & $\begin{array}{c}-0,001 * \\
(0.02)\end{array}$ & $\begin{array}{l}-0,01 \\
(0.01)\end{array}$ & $\begin{array}{c}-0,07 * * \\
(0.05)\end{array}$ & $\begin{array}{l}-0,06 \\
(0.05)\end{array}$ & $\begin{array}{c}0,03 * * \\
(0.04)\end{array}$ & $\begin{array}{c}0,06 \\
(0.05)\end{array}$ \\
\hline Div & $\begin{array}{c}1,50 * * * \\
(0.6)\end{array}$ & $\begin{array}{l}-0,6 \\
(0.5)\end{array}$ & $\begin{array}{l}0,06 \\
(0.8)\end{array}$ & $\begin{array}{l}-0,07 \\
(2.12)\end{array}$ & $\begin{array}{l}0,75 \\
(0.8)\end{array}$ & $\begin{array}{c}-7,9 \\
(2.00)\end{array}$ \\
\hline $\operatorname{Ln}(\text { size })_{t-1}$ & $\begin{array}{c}2,30 * * * \\
(1.2)\end{array}$ & $\begin{array}{c}3,6 * * * \\
(0.5)\end{array}$ & $\begin{array}{c}0,54 * * \\
(1.7)\end{array}$ & $\begin{array}{l}0,24 \\
(2.1)\end{array}$ & $\begin{array}{c}4,21 * * * \\
(1.6)\end{array}$ & $\begin{array}{l}3,64 * \\
(2.1)\end{array}$ \\
\hline Inflation & $\begin{array}{c}-0,07 * * \\
(0,05)\end{array}$ & $\begin{array}{c}0,04 \\
(0,07)\end{array}$ & $\begin{array}{c}0,06 \\
(0,05)\end{array}$ & $\begin{array}{r}-0,15 \\
(0,1)\end{array}$ & $\begin{array}{l}-0,01 \\
(0,06)\end{array}$ & $\begin{array}{l}0,19 \\
(0,1)\end{array}$ \\
\hline GDP & $\begin{array}{l}-0,01 \\
(0,06)\end{array}$ & $\begin{array}{c}0,09 \\
(0,07)\end{array}$ & $\begin{array}{l}-0,09 \\
(0,1)\end{array}$ & $\begin{array}{l}-0,25 \\
(0,2)\end{array}$ & $\begin{array}{c}-0,01 * * * \\
(0,09)\end{array}$ & $\begin{array}{c}0,35 \\
(0,18)\end{array}$ \\
\hline Constant & $\begin{array}{c}49,5 * * * \\
(5,98)\end{array}$ & $\begin{array}{c}32,2 * * * \\
(8,7)\end{array}$ & $\begin{array}{c}65,2 * * \\
(3,7)\end{array}$ & $\begin{array}{l}65,7 * * \\
(33,2)\end{array}$ & $\begin{array}{l}-52,7 * * \\
(26.54)\end{array}$ & $\begin{array}{l}-37,4 * \\
(8,92)\end{array}$ \\
\hline $\mathrm{R}^{2}$ & 0,33 & 0,38 & 0,17 & 0,06 & 0,21 & 0,03 \\
\hline Wald Chi 2 & $1,24 * * *$ & $1,50 * * *$ & $3,48 * * *$ & $7,06 * * *$ & $9,6 * * *$ & $7,15 * * *$ \\
\hline N. Obs. & 805 & 596 & 800 & 582 & 800 & 590 \\
\hline
\end{tabular}

When splitting the sample into IBs, CBs, and HBs as shown in Table 7, the results confirm the contribution of the standard corporate approach in explaining leverage mainly for listed banks. We observe some differences between all categories of banks confirming the hypothesis 1. Globally, we find that larger listed IBs and CBs with greater market to book ratio, greater dividend payout, lower profitability, and lower collaterals tend to be more leveraged, which aligns with those of Octavia and Brown (2010) for listed banks in developing countries. The results for IBs are consistent with Bitar et al. (2018) when focusing in the impact of size, profitability, and collaterals on leverage. Our results for IBs are also similar to Hoque and Liu (2021) findings regarding profitability, size, collaterals, and MTB. 
Furthermore, compared to listed CBs, market to book and collaterals are observed to have approximately the same significant impact on non-equity financing of listed IBs. In contrast, size and profitability have a significantly greater impact on leverage (Models 1 and 3, table 7). As for IBs, the trade-off arguments are similar, and asymmetry is lower, size appears to have a greater positive impact on leverage for IBs than CBs and HBs for both listed and unlisted banks. Similarly, we find a higher impact of profitability on leverage for IBs than for $\mathrm{CBs}$ due to the weaker arguments of the pecking order theory in IBs. For the same arguments, dividend payout has a lower impact (insignificant) on leverage in IBs than CBs. Finally, when focusing on unlisted banks, the standard corporate approach appears to explain better IBs' capital structure (Model 2).

Table 7: Corporate finance approach. Period 2008-2016. The dependent variable: Leverage

\begin{tabular}{|c|c|c|c|c|c|c|}
\hline & \multicolumn{2}{|c|}{ Panel A: (IBs) } & \multicolumn{2}{|c|}{ Panel B: (CBs) } & \multicolumn{2}{|c|}{ Panel C: (HBs) } \\
\hline \multirow{4}{*}{$\begin{array}{l}\text { MTB t-1 } \\
\text { (Std Err) }\end{array}$} & Listed & Unlisted & Listed & Unlisted & Listed & Unlisted \\
\hline & (1) & (2) & (3) & (4) & (5) & (6) \\
\hline & $0,78 * *$ & & $0,74 * * *$ & & $0,47 * *$ & \\
\hline & $(0.4)$ & & $(0.2)$ & & $(0.2)$ & \\
\hline \multirow{2}{*}{$\operatorname{Prof}_{\mathrm{t}-1}$} & $-0,54 * * *$ & $-0,41$ & $-0,15$ & 0,09 & 0,18 & $0,06 * * *$ \\
\hline & $(0.1)$ & $(0,3)$ & $(0.20)$ & $(0,5)$ & $(0,4)$ & $(0,3)$ \\
\hline \multirow{2}{*}{ Coll $_{t-1}$} & $-0,06 * *$ & $-0,06^{* *}$ & $-0,06^{* * *}$ & 0,03 & $0,13 * * *$ & $-0,02$ \\
\hline & $(0.04)$ & $(0.03)$ & $(0.02)$ & $(0.04)$ & $(0.8)$ & $(0.02)$ \\
\hline \multirow{2}{*}{ Div } & 0,23 & $-2,48 * *$ & $0,85^{*}$ & 0,04 & $-0,36^{*}$ & $1,48^{*}$ \\
\hline & $(0.9)$ & $(0,9)$ & $(1,1)$ & (1.2) & $(0,5)$ & $(0,80)$ \\
\hline \multirow{2}{*}{ Size $_{t-1}$} & $5,53 * * *$ & $5,00 * *$ & $1,39 * * *$ & $3,00 *$ & $-1,27 * *$ & 0,64 \\
\hline & $(0.66)$ & $(1,8)$ & $(2,08)$ & (1.6) & $(1,5)$ & $(1,2)$ \\
\hline \multirow{2}{*}{ Inflation } & $-0,15^{* * *}$ & 0,05 & $-0,10 * * *$ & 0,02 & 0,06 & 0,004 \\
\hline & $(0.09)$ & $(0,1)$ & $(0,06)$ & $(0.08)$ & $(0,08)$ & $(0,07)$ \\
\hline \multirow{2}{*}{ GDP } & $0,01 * * *$ & $-0,04$ & 0,08 & $0,21 * *$ & $-1,18 * * *$ & $-0,14$ \\
\hline & $(0.15)$ & $(0.1)$ & $(0.06)$ & $(0.08)$ & $(0.06)$ & $(0.08)$ \\
\hline \multirow{2}{*}{ Constant } & 13,2 & 15,62 & $66,5 * * *$ & $37,9 * * *$ & $102,8 * * *$ & $78,9 * * *$ \\
\hline & $(13,5)$ & $(27,9)$ & $(7,4)$ & $(3,26)$ & $(8,75)$ & $(19,4)$ \\
\hline $\mathrm{R}^{2}$ & 0,47 & 0,45 & 0,35 & 0,43 & 0,19 & 0,53 \\
\hline Wald Chi2 & $1,87 * * *$ & $11,48^{*}$ & $1,008 * * *$ & $3,64 * * *$ & $2,6 * * *$ & $1,65 * * *$ \\
\hline N. Obs. & 160 & 138 & 519 & 376 & 126 & 82 \\
\hline
\end{tabular}

Models 1 to 12 in Table 8 present the estimation results of the standard corporate regression on deposit and non-deposit ratios for IBs, CBs and HBs. Empirical results show an effective substitution between deposit and non-deposit liabilities.

Globally, we find that the corporate approach works less for the components of leverage, and the variables of the standard corporate finance approach do not retain their importance. When considering the $\mathrm{R}^{2}$ in Table 6 , we observe that values are higher for 
regressions on bank leverage than regressions on bank deposit and non-deposit liabilities. The standard corporate models' weak explanation power is also confirmed when we consider each bank type separately, where fewer variables are significant in the standard corporate approach (see Tables 7 versus 8). These results are consistent with regulation as a second approach to explain capital structure. Our results are in line with Berger et al. (1995) and Gropp and Heider (2010) who argue that corporate capital structure theories cannot be fully applied to banks due to regulation and the specific capital structure of banks where deposits are an essential component in financing sources.

Table 8: Corporate finance approach. IBs, CBs and HBs. Period 2008-2016

The dependent variables: Deposits and Non-Deposits Liabilities

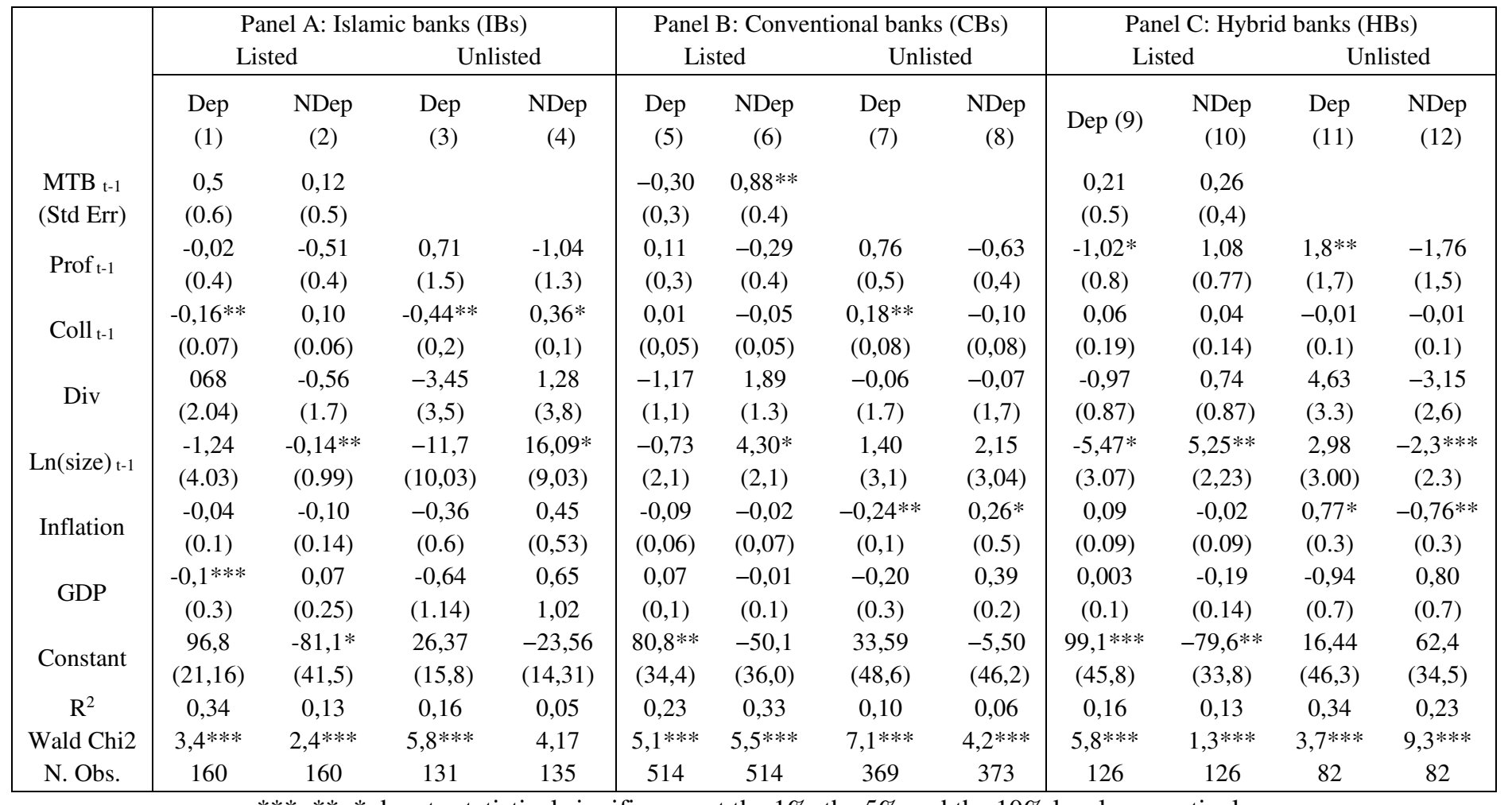

$* * *, * *, *$ denote statistical significance at the $1 \%$, the $5 \%$ and the $10 \%$ level, respectively

\subsection{Regression results: the regulatory approach}

Table 9 and Table 10 report results based on the regulatory approach. The variables Risk and the availability of deposit insurance schemes are added to all regressions as explanatory variables.

As shown in Models 5-8 in Table 9, Risk is observed to have a significant positive (negative) impact on deposit liabilities (respectively non-deposits). The higher risk the outside 
investors face, the more discount they demand on the price of issued securities. Consequently, banks will prefer financing through free-risk debt or low risk-debt instead of equity. However, when splitting the sample into IBs, CBs and HBs (Table 10), we find that risk drives the regulatory capital only for conventional banks. The impact of risk appears lower for IBs, confirming our second hypothesis Hyp 2. From a regulatory point of view, regulators could force riskier banks to hold more regulatory capital to protect themselves against costs of financial distress (Berger et al. 1995; Gropp and Heider 2010; Octavia and Brown 2010). In the Islamic banking context, the ability to engage in reckless economic behavior, as well as the incentives shareholders to increase risks, are limited firstly by the requirement to conform to Islamic finance morals and secondly, by the availability of SSB in the governance structure that guarantees to all stakeholders' compliance with Islamic finance rules.

Table 9: Regulatory approach, all banks. Period 2008-2016

\begin{tabular}{|c|c|c|c|c|c|c|c|c|}
\hline & \multicolumn{2}{|c|}{ Regulatory capital } & \multicolumn{2}{|c|}{ Leverage } & \multicolumn{2}{|c|}{ Deposits ratio } & \multicolumn{2}{|c|}{ Ndeposits ratio } \\
\hline & (1) & (2) & (3) & (4) & (5) & (6) & (7) & (8) \\
\hline & Listed & Unlisted & Listed & Unlisted & Listed & Unlisted & Listed & Unlisted \\
\hline $\begin{array}{l}\text { MTB }_{\mathrm{t}-1} \\
\text { (Std Err) }\end{array}$ & $\begin{array}{c}0.02 \\
(0.17)\end{array}$ & & $\begin{array}{c}0.76 * * * \\
(0.2)\end{array}$ & & $\begin{array}{c}2.64 * * * \\
(0.4)\end{array}$ & & $\begin{array}{c}-1.94 * * * \\
(0.37)\end{array}$ & \\
\hline $\operatorname{Prof}_{t-1}$ & $\begin{array}{c}0.56 * * * \\
(0.15)\end{array}$ & $\begin{array}{c}1.45 * * * \\
(0.26)\end{array}$ & $\begin{array}{c}-2.01 * * * \\
(0.14)\end{array}$ & $\begin{array}{c}-1.24 * * * \\
(0.21)\end{array}$ & $\begin{array}{c}-2.31 * * * \\
(0.3)\end{array}$ & $\begin{array}{c}-1.61 * * \\
(0.71)\end{array}$ & $\begin{array}{c}0.41 * * * \\
(0.29)\end{array}$ & $\begin{array}{c}0.63 \\
(0.66)\end{array}$ \\
\hline Coll $_{\mathrm{t}-1}$ & $\begin{array}{c}0.04 * * * \\
(0.01)\end{array}$ & $\begin{array}{c}0.04 * * * \\
(0.01)\end{array}$ & $\begin{array}{l}-0.001 \\
(0.01)\end{array}$ & $\begin{array}{l}-0.01 \\
(0.01)\end{array}$ & $\begin{array}{l}-0.01 \\
(0.02)\end{array}$ & $\begin{array}{l}-0.05 \\
(0.04)\end{array}$ & $\begin{array}{l}-0.005 \\
(0.02)\end{array}$ & $\begin{array}{c}0.03 \\
(0.04)\end{array}$ \\
\hline Div & $\begin{array}{l}0.19 \\
(0.5)\end{array}$ & $\begin{array}{l}-0.09 \\
(0.73)\end{array}$ & $\begin{array}{c}0.97 * \\
(0.5)\end{array}$ & $\begin{array}{c}0.12 \\
(0.65)\end{array}$ & $\begin{array}{l}2.71 * * \\
(1.21)\end{array}$ & $\begin{array}{c}7.04 * * * \\
(2.28)\end{array}$ & $\begin{array}{l}-1.64 \\
(1.05)\end{array}$ & $\begin{array}{c}-6.85 * * * \\
(2.15)\end{array}$ \\
\hline Size $_{t-1}$ & $\begin{array}{c}-0.61 * * * \\
(0.11)\end{array}$ & $\begin{array}{c}-1.14 * * * \\
(0.19)\end{array}$ & $\begin{array}{c}1.01 * * * \\
(0.13)\end{array}$ & $\begin{array}{c}1.96 * * * \\
(0.17)\end{array}$ & $\begin{array}{c}-1.85 * * * \\
(0.24)\end{array}$ & $\begin{array}{c}2.04 * * * \\
(0.57)\end{array}$ & $\begin{array}{c}2.57 * * * \\
(0.22)\end{array}$ & $\begin{array}{c}0.01 \\
(0.53)\end{array}$ \\
\hline $\operatorname{Risk}_{\mathrm{t}-1}$ & $\begin{array}{l}-0.06 \\
(0.18)\end{array}$ & $\begin{array}{l}-0.26 \\
(0.27)\end{array}$ & $\begin{array}{c}0.24 \\
(0.19)\end{array}$ & $\begin{array}{l}-0.13 \\
(0.24)\end{array}$ & $\begin{array}{c}1.67 * * * \\
(0.19)\end{array}$ & $\begin{array}{l}1.82 * * \\
(0.86)\end{array}$ & $\begin{array}{c}-1.41 * * * \\
(0.37)\end{array}$ & $\begin{array}{c}-2.56 * * * \\
(0.79)\end{array}$ \\
\hline DepInsurance & $\begin{array}{c}-0.65^{* *} \\
(0.3)\end{array}$ & $\begin{array}{c}-1.51 * * * \\
(0.27)\end{array}$ & $\begin{array}{c}0.75 * * \\
(0.3)\end{array}$ & $\begin{array}{c}0.45 \\
(0.41)\end{array}$ & $\begin{array}{c}-1.61 * * \\
(0.71)\end{array}$ & $\begin{array}{l}-1.86 \\
(1.47)\end{array}$ & $\begin{array}{c}2.38 * * * \\
(0.64)\end{array}$ & $\begin{array}{l}2.47 * \\
(1.4)\end{array}$ \\
\hline Inflation & $\begin{array}{c}0.03 \\
(0.04)\end{array}$ & $\begin{array}{c}0.04 \\
(0.09)\end{array}$ & $\begin{array}{c}-0.13 * * * \\
(0.04)\end{array}$ & $\begin{array}{l}0.13 * \\
(0.07)\end{array}$ & $\begin{array}{l}-0.01 \\
(0.09)\end{array}$ & $\begin{array}{c}0.50 \\
(0.28)\end{array}$ & $\begin{array}{l}-0.15^{*} \\
(0.08)\end{array}$ & $\begin{array}{c}0.50 \\
(0.28)\end{array}$ \\
\hline GDP & $\begin{array}{c}-0.13 * * * \\
(0.04)\end{array}$ & $\begin{array}{l}-0.11 \\
(0.11)\end{array}$ & $\begin{array}{c}0.36 * * * \\
(0.04)\end{array}$ & $\begin{array}{c}0.06 \\
(0.07)\end{array}$ & $\begin{array}{c}0.55 * * * \\
(0.11)\end{array}$ & $\begin{array}{l}-0.15 \\
(0.28)\end{array}$ & $\begin{array}{c}0.20 * * \\
(0.1)\end{array}$ & $\begin{array}{l}-0.15 \\
(0.28)\end{array}$ \\
\hline Constant & $\begin{array}{c}22.69 * * * \\
(2.04)\end{array}$ & $\begin{array}{c}31.7 * * * \\
(3.37)\end{array}$ & $\begin{array}{c}73.05 * * * \\
(1.87)\end{array}$ & $\begin{array}{c}60.03 * * * \\
(2.85)\end{array}$ & $\begin{array}{c}88.7 * * * \\
(4.38)\end{array}$ & $\begin{array}{c}28.02 * * * \\
(2.85)\end{array}$ & $\begin{array}{c}-13.1 * * * \\
(3.9)\end{array}$ & $\begin{array}{c}33.68 * * * \\
(9.42)\end{array}$ \\
\hline Wald Chi 2 & $45.5 * * *$ & $86.03 * * *$ & $260.9 * * *$ & $164.7 * * *$ & $31.4 * * *$ & $71.85^{* * *}$ & $-13.1 * * *$ & $71.85^{* * *}$ \\
\hline $\mathrm{R}^{2}$ & 0.10 & 0.23 & 0.29 & 0.30 & 0.20 & 0.07 & 0.20 & 0.05 \\
\hline $\begin{array}{c}\text { Number of } \\
\text { banks }\end{array}$ & 189 & 197 & 189 & 197 & 189 & 197 & 189 & 197 \\
\hline
\end{tabular}

Besides, results in Table 9 reveal that deposit insurance schemes are negatively associated with the regulatory capital at $5 \%$ and $1 \%$ level for listed and unlisted banks, respectively (Models 1 and 2). We also find that listed banks under the protection of deposit insurance schemes tend to have higher leverage (Models 3 and 4). Our results are consistent 
with the related theory on the effect of regulation and safety nets on capital structure. Safety nets tend to reduce the bank level of capital requirement since their introduction reduces the likelihood of bank failure and isolates banks from the potential market discipline (Berger et al. 1995). The introduction of deposit insurance schemes in banks leads thus to lower capital levels and higher leverage compared to banks with similar portfolios not subject to deposit insurance (Berger et al. 1995). Our result is consistent with these banks having better access to debt markets because they may be less likely to default as we observe a significant positive impact on non-deposit liabilities for listed and unlisted banks (Models 7 and 8, Table 9).

Table 10: Regulatory approach. IBs, CBs and HBs capital structure determinants. Period: 2008-2016 The dependent variable: The regulatory capital (RegCap)

\begin{tabular}{|c|c|c|c|c|c|c|c|c|c|c|}
\hline \multirow[b]{3}{*}{$\begin{array}{l}\text { MTB }_{\mathrm{t}-1} \\
\text { (Std Err) }\end{array}$} & \multicolumn{4}{|c|}{$\begin{array}{l}\text { Panel A: } \\
\text { Islamic banks } \\
\text { (IBs) }\end{array}$} & \multicolumn{2}{|c|}{$\begin{array}{c}\text { Panel B: } \\
\text { Conventional banks } \\
\text { (CBs) }\end{array}$} & \multicolumn{2}{|c|}{$\begin{array}{c}\text { Panel C: } \\
\text { Hybrid banks } \\
\text { (HBs) }\end{array}$} & \multicolumn{2}{|c|}{$\begin{array}{l}\text { Panel D: } \\
\text { All banks }\end{array}$} \\
\hline & \multicolumn{2}{|c|}{ Listed } & \multicolumn{2}{|c|}{ Unlisted } & Listed & Unlisted & Listed & Unlisted & Listed & Unlisted \\
\hline & $\begin{array}{c}(1) \\
-0,13 \\
(0.63)\end{array}$ & $\begin{array}{c}(2) \\
-0,003 \\
(0.5)\end{array}$ & (3) & (4) & $\begin{array}{c}(5) \\
-0,56^{* *} \\
(0.2)\end{array}$ & (6) & $\begin{array}{c}(7) \\
-0,39 * \\
(0.2)\end{array}$ & (8) & $\begin{array}{c}(9) \\
-0,46 * \\
(0.2)\end{array}$ & (10) \\
\hline $\operatorname{Prof}_{t-1}$ & $\begin{array}{c}0,86 * * \\
(0.4)\end{array}$ & $\begin{array}{c}0,88 * * \\
(0.3)\end{array}$ & $\begin{array}{c}0,28 \\
(0,25)\end{array}$ & $\begin{array}{c}0,4^{*} \\
(0.24)\end{array}$ & $\begin{array}{c}0,002 \\
(0.3)\end{array}$ & $\begin{array}{c}1,33 * * \\
(0.5)\end{array}$ & $\begin{array}{l}0,83 \\
(0.5)\end{array}$ & $\begin{array}{l}-0,31 \\
(1.5)\end{array}$ & $\begin{array}{c}0,53 * * \\
(0.2)\end{array}$ & $\begin{array}{c}0,68 * * * \\
(0.2)\end{array}$ \\
\hline Coll $_{\mathrm{t}-1}$ & $\begin{array}{l}-0,04 \\
(0.03)\end{array}$ & $\begin{array}{c}-0,04 \\
(0.03)\end{array}$ & $\begin{array}{c}0,03 \\
(0.04)\end{array}$ & $\begin{array}{c}0,07 \\
(0.05)\end{array}$ & $\begin{array}{c}0,05 \\
(0.03)\end{array}$ & $\begin{array}{l}0,002 \\
(0.03)\end{array}$ & $\begin{array}{c}0,02 \\
(0.05)\end{array}$ & $\begin{array}{c}0,08 \\
(0.06)\end{array}$ & $\begin{array}{c}0,02 \\
(0.02)\end{array}$ & $\begin{array}{c}0,02 \\
(0.03)\end{array}$ \\
\hline Div & $\begin{array}{l}1,87^{*} \\
(1.06)\end{array}$ & $\begin{array}{l}2,01 * \\
(1.07)\end{array}$ & $\begin{array}{l}0,27 \\
(1.1)\end{array}$ & $\begin{array}{c}1,41 \\
(1.22)\end{array}$ & $\begin{array}{c}-0,02 \\
(0.7)\end{array}$ & $\begin{array}{c}-3,5 * * \\
(1.5)\end{array}$ & $\begin{array}{c}-2,29 * * \\
(0.9)\end{array}$ & $\begin{array}{c}0,3 \\
(1.9)\end{array}$ & $\begin{array}{l}0,19 \\
(0.6)\end{array}$ & $\begin{array}{c}-1,02 \\
(0.9)\end{array}$ \\
\hline $\operatorname{Size}_{\mathrm{t}-1}$ & $\begin{array}{c}-3,56 * * \\
(1.6)\end{array}$ & $\begin{array}{c}-3,4 * * \\
(1.6)\end{array}$ & $\begin{array}{l}-1,14 \\
(1,08)\end{array}$ & $\begin{array}{l}-0,25 \\
(1.02)\end{array}$ & $\begin{array}{c}-0,81 * \\
(0.4)\end{array}$ & $\begin{array}{c}-2,32 * * * \\
(0.5)\end{array}$ & $\begin{array}{l}-0,93 \\
(0.6)\end{array}$ & $\begin{array}{c}-0,89^{*} \\
(0.6)\end{array}$ & $\begin{array}{c}-1,1^{* * *} * \\
(0.4)\end{array}$ & $\begin{array}{c}-2,12 * * * \\
(0.4)\end{array}$ \\
\hline Risk $_{\mathrm{t}-1}$ & $\begin{array}{l}-0,27 \\
(0.4)\end{array}$ & $\begin{array}{l}-0,26 \\
(0.5)\end{array}$ & $\begin{array}{c}0,76 \\
(0,67)\end{array}$ & $\begin{array}{c}0,41 \\
(0.58)\end{array}$ & $\begin{array}{c}0,46 * * \\
(0.2)\end{array}$ & $\begin{array}{l}0,41 \\
(0.4)\end{array}$ & $\begin{array}{c}-0,6^{* * *} \\
(0.3)\end{array}$ & $\begin{array}{c}0,7 \\
(0.8)\end{array}$ & $\begin{array}{c}-0,06 \\
(0.2)\end{array}$ & $\begin{array}{l}0,33 \\
(0,2)\end{array}$ \\
\hline DepInsurance & $\begin{array}{l}-1,46 \\
(1.3)\end{array}$ & & $\begin{array}{c}-2,9 * * * \\
(1,33)\end{array}$ & & $\begin{array}{l}-0,60 \\
(0.9)\end{array}$ & $\begin{array}{l}-0,67 \\
(1.1)\end{array}$ & $\begin{array}{l}-0,68 \\
(1.1)\end{array}$ & $\begin{array}{l}-0,86 \\
(2.7)\end{array}$ & $\begin{array}{c}-0,89 * * \\
(0.7)\end{array}$ & $\begin{array}{c}1,46^{* *} \\
(0.7)\end{array}$ \\
\hline ShDepInsurance & & $\begin{array}{l}-0,51 \\
(2.06)\end{array}$ & & $\begin{array}{c}-5,48 * * \\
(1.1)\end{array}$ & & & & & & \\
\hline Inflation & $\begin{array}{l}-0,04 \\
(0.1)\end{array}$ & $\begin{array}{l}-0,03 \\
(0.1)\end{array}$ & $\begin{array}{c}-0,17 \\
(0.2)\end{array}$ & $\begin{array}{l}-0,15 \\
(0.3)\end{array}$ & $\begin{array}{c}0,13 * * * \\
(0.04)\end{array}$ & $\begin{array}{l}0,19 * \\
(0.11)\end{array}$ & $\begin{array}{l}-0,10 \\
(0.1)\end{array}$ & $\begin{array}{l}0,20 \\
(0.2)\end{array}$ & $\begin{array}{c}0,06 \\
(0.04)\end{array}$ & $\begin{array}{c}0,04 \\
(0.09)\end{array}$ \\
\hline GDP & $\begin{array}{c}-0,4 * * * \\
(0.1)\end{array}$ & $\begin{array}{c}-0,4 * * * \\
(0.1)\end{array}$ & $\begin{array}{l}-0,6 \\
(0.4)\end{array}$ & $\begin{array}{c}-0,99 * * \\
(0.4)\end{array}$ & $\begin{array}{l}-0,13 \\
(0.09)\end{array}$ & $\begin{array}{l}-0,31 * \\
(0.18)\end{array}$ & $\begin{array}{l}0,03 \\
(0.1)\end{array}$ & $\begin{array}{l}-0,16 \\
(0.1)\end{array}$ & $\begin{array}{c}-0,13 * * \\
(0.07)\end{array}$ & $\begin{array}{c}-0,23 \\
(0.1)\end{array}$ \\
\hline Constant & $\begin{array}{c}75,8 * * * \\
(26.5)\end{array}$ & $\begin{array}{c}72,4 * * * \\
(26.4)\end{array}$ & $\begin{array}{l}33,2 * \\
(17,2)\end{array}$ & $\begin{array}{c}19,3 \\
(17,2)\end{array}$ & $\begin{array}{c}25,3 * * * \\
(2.45)\end{array}$ & $\begin{array}{c}52,6^{* * * *} \\
(10,5)\end{array}$ & $\begin{array}{c}33,2 * * * \\
(11,2)\end{array}$ & $\begin{array}{c}21,5 * * * \\
(9.08)\end{array}$ & $\begin{array}{c}33,8 * * * \\
(6,8)\end{array}$ & $\begin{array}{c}47,4 * * * \\
(7,7)\end{array}$ \\
\hline $\mathrm{R}^{2}$ & 0,38 & 0,37 & 0,46 & 0,35 & 0,14 & 0,44 & 0,28 & 0,21 & 0,13 & 0,23 \\
\hline Wald Chi2 & $5,08 * * *$ & $5,16^{* * * *}$ & $25,5^{* * * *}$ & $50,79 * * *$ & $11,05^{* *}$ & $6,1^{*}$ & $8,86^{*}$ & $74,73 * * *$ & $13,5 * *$ & $14,8^{* *}$ \\
\hline $\begin{array}{c}\text { Number of } \\
\text { banks }\end{array}$ & 117 & 117 & 78 & 78 & 345 & 213 & 108 & 52 & 566 & 335 \\
\hline
\end{tabular}

$* * *, * *$ and $*$ denote statistical significance at the $1 \%, 5 \%$ and $10 \%$ level respectively.

However, when considering the different categories of banks, the significant negative impact of explicit deposit insurance schemes on the regulatory capital is only confirmed for unlisted IBs (see Table 10). Regarding IBs, the Shari'ah-compliant deposit insurance scheme has a more pronounced significant negative impact on the regulatory capital than the conventional deposit insurance scheme, confirming our third hypothesis (Hyp 3). Our results indicate that IBs under Shari'ah-compliant deposits insurance scheme tend to have lower 
capital requirements (Models 3 and 4, Table 10). Our findings are in line with Aysan et al. (2016), who found that conventional deposit insurance increases IBs depositors' market discipline, compared with a situation where IBs are under the protection of Islamic deposit insurance. In light of this conclusion, IBs subject to Islamic deposit insurance face lower market discipline and thus the related liquidity problems which lead to lower capital requirement compared with banks subject to conventional deposit insurance schemes.

\section{Conclusion}

The objective of the chapter is to understand the capital structure of IBs, CBs, and HBs. We build on the theoretical contributions of the classical financial theories to explore the impact of Islamic principles on the capital structure of banks. We have considered both corporate finance and regulatory approaches. We empirically investigated factors that significantly affect IBs, CBs, and HBs capital structure by considering listed and unlisted banks. Depending on the approach considered, we integrate several measures of capital structure.

Regarding the corporate approach, we identify profitability, market to book ratio, dividend, collateral, and size as specific bank determinants of capital structure. When considering the regulatory approach, we add risk and deposit insurance schemes as additional determinants. To conduct our analysis, we make several sup-samples and run panel regressions. The sample includes 386 banks categorized into 74 IBs, 256 fully-CBs, and 56 HBs from 20 countries for 2008 - 2016. In sum, from a corporate finance approach, we assumed that the trade-off arguments are similar but that the pecking order arguments are weaker due to lower information asymmetries in the Islamic finance context. The differences captured between the regression results for IBs, CBs and HBs offer a first empirical confirmation that the information asymmetries are less important in IBs, thus changing the equity and non-equity financing level and the extent of the impact of determinants. When considering the regulatory approach, we find that impact of Islamic deposit insurance is observed to be negatively and significantly important, revealing that IBs subject to Islamic deposit insurance hold lower capital requirement levels than other IBs subject to conventional deposit insurance.

The results presented extend the literature on bank capitalization in developing and Islamic financial markets and has important policy implications. As current international financial markets and regulatory standards evolve in order to develop sound financial systems 
and bank governance, our results help explain how Islamic bank managers choose between debt and equity financing, especially in developing countries.

For research limitations, the study has not constructed a new capital structure theory specific to IBs but only apply the classical concepts and theories of capital structure (information asymmetry, agency theory, trade-off theory, pecking order theory) to the Islamic context. Despite these interesting results, the determinants of capital structure of IBs cannot probably be explained only by traditional capital structure theories.

For future research, specific theories should be developed to discover specific determinants of IBs' capital structure. Exploring these new determinants requires considering the presence of dual governance systems and the ethical constraints. This specific framework is necessary to avoid applying models grounded on expected utility maximization choice theory in a context where ethical objectives and constraints are important.

\section{References}

Abdelsalam O, Dimitropoulos P, Elnahass M, Leventis S (2016) Earnings management behaviors under different monitoring mechanisms: The case of Islamic and conventional banks. J Econ Behav Organ 132:155-173

Abdul Karim M, Hassan MK, Hassan T, Mohamad S (2014) Capital adequacy and lending and deposit behaviors of conventional and Islamic banks. Pacific Basin Financ J 28:5875. doi: 10.1016/j.pacfin.2013.11.002

Abdullah WAW, Percy M, Stewart J (2015) Determinants of voluntary corporate governance disclosure: Evidence from Islamic banks in the Southeast Asian and the Gulf Cooperation Council regions. J Contemp Account Econ 11:262-279. doi: 10.1016/j.jcae.2015.10.001

Abedifar P, Molyneux P, Tarazi A (2013) Risk in islamic banking. Rev Financ 17:2035-2096

Allen F, Carletti E, Marquez R (2014) Deposits and bank capital structure. J financ econ 118:601-619. doi: 10.1016/j.jfineco.2014.11.003

Antoniou A, Guney Y, Paudyal K (2008) The Determinants of Capital Structure: Capital Market-Oriented versus Bank-Oriented Institutions. J Financ Quant Anal 43:59-92. doi: $10.2307 / 27647340$

Archer S, Karim RAA (2009) Profit-sharing investment accounts in Islamic banks: Regulatory problems and possible solutions. J Bank Regul 10:300-306

Archer S, Karim RAA (2006) On capital structure, risk sharing and capital adequacy in Islamic banks. Int J Theor Appl Financ 9:269-280

Archer S, Karim RAA, Al-Deehani T (1998) Financial contracting, governance structures and the accounting regulation of Islamic banks: An analysis in terms of agency theory and transaction cost economics. J Manag Gov 2:149-170. doi: 10.1023/A:1009985419353

Athari SA, Adaoglu C, Bektas E (2016) Investor protection and dividend policy: The case of Islamic and conventional banks. Emerg Mark Rev 27:100-117. doi: 10.1016/j.ememar.2016.04.001 
Aysan A, Disli M, Ozturk H, Turhan I (2015) Are Islamic Banks Subject To Depositor Discipline? Singapore Econ Rev 60:1550007. doi: 10.1142/S0217590815500071

Aysan AF, Disli M, Duygun M, Ozturk H (2016) Islamic Banks, Deposit Insurance Reform, and Market Discipline: Evidence from a Natural Framework. J Financ Serv Res 1-26

Barry TA, Lepetit L, Tarazi A (2011) Ownership structure and risk in publicly held and privately owned banks. J Bank Financ 35:1327-1340

Basel Committee on Banking Supervision (2011) Basel III: A Global Regulatory Framework for More Resilient Banks and Banking Systems (Bank for International Settlements, December 2010; revised June 2011)

Beck T, Demirgüç-Kunt A, Merrouche O (2013) Islamic vs. conventional banking: Business model, efficiency and stability. J Bank Financ 37:433-447

Berger A, Herring R, Szegö G (1995) The role of capital in financial institutions. J Bank Financ 19:393-430. doi: 10.1016/0378-4266(95)00002-X

Bitar M, Kabir Hassan M, Hippler WJ (2018) The determinants of Islamic bank capital decisions. Emerg Mark Rev 35:48-68. doi: 10.1016/j.ememar.2017.12.002

Bitar M, Madiès P (2017) What makes Islamic banks different? a multivariate appraoch. Econ Syst 41:215-235

Bitar, M., \& Tarazi, A. (2018). Creditor rights and bank capital decisions: Conventional vs. Islamic banking. Journal of Corporate Finance, 55, 69 - 104.

Booth L, Varouj A, Asli D-K, Vojislav M (2001) Capital structure in developping countries. J Finance 56:87-130

Caglayan E, Sak N (2010) The determinants of capital structure: evidence from the Turkish banks. J Money, Invest Bank 15:57-65

Calomiris CW (1999) Building an incentive-compatible safety net. J Bank Financ 23:1499_ 1519. doi: 10.1016/S0378-4266(99)00028-X

Čihák M, Hesse H (2010) Islamic Banks and Financial Stability: An Empirical Analysis. J Financ Serv Res 38:95-113

Crotty J (2009) Structural causes of the global financial crisis: a critical assessment of the 'new financial architecture. Cambridge J Econ 33:563-580

De Haan J, Vlahu R (2016) Corporate governance of banks: A survey. J Econ Surv 30:228277. doi: 10.1111/joes.12101

Diamond D, Dybvig P (1983) Bank Runs, Deposit Insurance, and Liquidity. J Polit Econ 91:401-419

Diamond D, Rajan R (2000) A theory of bank capital. J Finance 55:2431-2465

Dietrich A, Wanzenried G (2011) Determinants of bank profitability before and during the crisis: Evidence from Switzerland. J Int Financ Mark Institutions Money 21:307-327

El-Hawary D (2004) Regulating Islamic Financial Institutions: The Nature of the Regulated. World Bank Policy Res Work Pap 3227:. doi: 10.1596/1813-9450-3227

El-Hawary D, Grais W, Iqbal Z (2007) Diversity in the regulation of Islamic Financial Institutions. Q Rev Econ Financ 46:778-800

Farag H, Mallin C, Ow-Yong K (2017) Corporate governance in Islamic banks: New insights for dual board structure and agency relationships. J Int Financ Mark Institutions Money. doi: 10.1016/j.intfin.2017.08.002

Farook S, Hassan MK, Clinch G (2012) Profit distribution management by Islamic banks: An empirical investigation. Q Rev Econ Financ 52:333-347

Frank MZ, Goyal VK (2009) Capital Structure Decisions: Which Factors Are Reliably Important? Fnancial Manag 38:1-37

Giordana G, Schumacher I (2013) What are the bank-specific and macroeconomic drivers of banks' leverage? Evidence from Luxembourg. Empir Econ 45:905-928. doi: $10.1007 / \mathrm{s} 00181-012-0643-8$ 
Gropp R, Heider F (2010) The determinants of bank capital structure. Rev Financ 587-622

Guizani, M. (2021) The determinants of capital structure of Islamic and conventional banks: an autoregressive distributed lag approach Journal of Islamic Accounting and Business Research, Vol. 12:131-147. https://doi.org/10.1108/JIABR-06-2020-0177

Guizani, M. and Ajmi, A.N. (2021) The capital structure decision of Islamic and conventional banks: empirical evidence from Malaysia. Asia-Pacific Journal of Business Administration, 13:216-234. https://doi.org/10.1108/APJBA-06-2020-0218

Haniffa R, Hudaib M (2007) Exploring the ethical identity of Islamic Banks via communication in annual reports. J Bus Ethics 76:97-116

Harris M, Raviv A (1990) Capital Structure and the Informational Role of Debt. J Finance 45:321-349

Harris M, Raviv A (1991) The Theory of Capital Structure. J Finance 46

Hoque H, Liu H (2021) Capital structure of Islamic banks: how different are they from conventional banks? Global Finance Journal, 100634

Jensen M (1986) American Economic Association Agency Costs of Free Cash Flow , Corporate Finance, and Takeovers Author ( $\mathrm{s}$ ): Michael C. Jensen Source: The American Economic Review, Vol . 76, No . 2 , Papers and Proceedings of the NinetyEighth Annual Meeting of the. Am Econ Rev 76:323-329

Jensen M, Meckling W (1976) Theory of the Firm: Managerial Behavior, Agency Costs, and Ownership Structure. J financ econ 53-82

Jung K, Kim Y, Stulz R (1996) Timing, investment opportunities, managerial discretion, and the security issue design. J financ econ 159-185

Kabir MN, Worthington A, Gupta R (2015) Comparative credit risk in Islamic and conventional bank. Pacific Basin Financ J 34:327-353

Köhler M (2014) Which banks are more risky? The impact of business models on bank stability. J Financ Stab 16:195-212

Lintner J (1965) The Valuation of Risk Assets and the Selection of Risky Investments in Stock Portfolio and Capital Budgets. Rev Econ Stat 13-37

Macey J., O'Hara M (2003) The corporate governance of banks. Econ Policy Rev 9:91-107

Merton R (1977) An analytic derivation of the cost of deposit insurance and loan guarantees: An application of modern option pricing theory. J Bank Financ 1:3-11

Meslier, C' eline, Risfandy, Tastaftiyan, \& Tarazi, Amine (2020). Islamic banks ' equity financing, Shariah supervisory board, and banking environments. Pacific-Basin

Finance Journal, 62, 101354.

Miller MH (1995) Do the MPropositions Apply to Banks? J Bank Financ 19:483-489

Modigliani F, Miller M (1958) The cost of capital, corporation finance, and the theory of investment. Am Econ Rev 48:261-297

Mokni RBS, Rachdi H (2014) Assessing the bank profitability in the MENA region: A comparative analysis between conventional and Islamic bank. Int J Islam Middle East Financ Manag 7:305-332

Mollah S, Hassan MK, Al Farooque O, Mobarek A (2016) The governance, risk-taking, and performance of Islamic banks. J Financ Serv Res 1-25

Mollah S, Zaman M (2015) Shari'ah supervision, corporate governance and performance: Conventional vs. Islamic banks. J Bank Financ 58:418-435

Mülbert P (2009) Corporate governance of banks. Eur Bus Organ Law Rev 10:411-436

Myers SC (1984) The capital structure puzzle. J Finance 34:575-592

Myers SC (1977) Determinants of corporate borrowing. J financ econ 147-175

Myers SC, Majluf N (1984) Corporate Financing and Investment Decisions When Firms Have Information That Investors Do Not Have. J financ econ 13:187-221

Octavia M, Brown R (2010) Determinants of bank capital structure in developing countries: 
regulatory capital requirement versus the standard determinants of capital structure. $\mathbf{J}$ Emerg Mark 15:50-62

Olson D, Zoubi T (2017) Convergence in bank performance for commercial and Islamic banks during and after the Global Financial Crisis. Q Rev Econ Financ 65:71-87

Olson D, Zoubi $\mathrm{T}$ (2008) Using accounting ratios to distinguish between Islamic and conventional banks in GCC region. Int $\mathrm{J}$ Account 45-65

Rajan, Zingales (1995) What Do We Know about Capital Structure?: Some Evidence from International Data. J Finance 50:1421-1460

Safieddine A (2009) Islamic financial institutions and corporate governance: New insights for agency theory. Corp Gov 17:142-158

Shibani O, De Fuentes C (2017) Differences and similaritites between corporate governance principles in Islamic banks and Conventional banks. Res Int Bus Financ 42:1005-1010. doi: 10.1016/j.ribaf.2017.07.036

Stulz R (1990) Managerial discretion and optimal financial policies. J financ econ 26:3-27

Titman S, Wessels R (1988) The determinants of capital structure choice. J Finance 43:1-19

Toumi K, Louhichi W, Viviani J-L (2012) Alternative Financial Decision Principles: Theoretical Foundations of Islamic Banks' Capital Structure. Recent Dev Altern Financ Empir Assessments Econ Implic (International Symp Econ Theory Econom Vol 22) William A Barnett, Fredj Jawadi Emerald Gr Publ Ltd 22:157-172

Toumi K, Viviani J-L (2013) Le risque lié aux comptes d'investissement participatifs : un risque propre aux banques islamiques. Rev des Sci Gest 48:131-142

Toumi K, Viviani J-L, Chayeh Z (2018) Measurement of the displaced commercial risk in Islamic Banks. Q Rev Econ Financ 1-14. doi: 10.1016/j.qref.2018.03.001

Williamson SD (1986) Costly monitoring, financial intermediation, and equilibrium credit rationing. J Monet Econ 18:159-179 